\title{
Energy Expenditure Does not Differ, but Protein Oxidation Rates Appear Lower in Meals Containing Predominantly Meat versus Soy Sources of Protein
}

\author{
Sze-Yen Tan ${ }^{\mathrm{a}}$ Marijka Batterham ${ }^{\mathrm{b}}$ Linda Tapsella \\ ${ }^{\mathrm{a}}$ Smart Foods Centre, \\ ${ }^{\mathrm{b}}$ Statistical Consulting Service, University of Wollongong, Australia
}

\section{Key Words \\ Dietary protein - Energy expenditure - Fat oxidation . Calorimetry}

\section{Summary}

Background: High protein meals produce 3 relevant effects in weight management: i) higher thermogenic cost, ii) enhanced fat oxidation, and iii) greater satiation. Pork has been reported to be more thermogenic than soy, suggesting meat protein may be superior to plant protein in a high-protein weight loss diet context. In this study, we aimed to compare the effects of high-protein meals using meat, dairy, and soy sources respectively. Methods: This crossover feeding trial measured energy expenditure, substrate oxidation, and satiety levels of 12 adults during 8-hour stays in a whole-room calorimeter. The 3 isoenergetic high-protein test meals $(30 \%$ protein, $40 \%$ carbohydrate, $30 \%$ fat) contained predominantly meat, dairy, and soy protein. Results: There was no significant difference between meals for effects on energy expenditure ( $p=0.987$ ), carbohydrate oxidation ( $p=0.951)$, and fat oxidation ( $p=0.997)$. Protein oxidation was significantly lower in meals with predominantly meat compared to soy sources $(p=0.012)$. There was no significant difference between meals for reported satiety levels ( $p=0.296$ ). Conclusion: High-protein meals may be argued as beneficial for weight loss. Animal protein does not appear to offer superior energy expenditure effects, but there may be protein-sparing effects with meat, which may be beneficial in terms of retaining lean body mass.

\section{Introduction}

Studies of human energy metabolism consistently report higher energy expenditure following consumption of highprotein meals [1], an effect attributed to the higher metabolic cost of amino acid metabolism in the human body [2]. In addition, a higher protein diet has been shown to increase fat oxidation acutely [3] and to produce higher satiety levels than standard low protein diets $[4,5]$. These effects may be particularly beneficial to obese individuals who have higher body energy stores and impaired fat oxidation as compared to their lean counterparts [6]. Higher satiating effects may mean reduced energy intake following high protein meals. Although fat oxidation rates between lean and obese adults appear similar after adjustment for body composition [3], fat oxidation in the obese remains important considering the presence of large amounts of adipose tissue and the need to protect lean body mass [1]. In this sense, diets with higher proportions of protein are thought to be particularly efficacious. Our previous research has revealed that energy- and fat oxidation-enhancing effects of higher-protein diets become greater as the body fat mass increases [7]. Not all protein-rich foods exhibit the same thermic effect in humans. A high-pork protein diet has been shown to induce energy expenditure $2 \%$ higher than a high-soy protein diet although both diets produced significantly higher energy expenditure $(3 \%)$ than a control lowprotein diet [8]. This was attributed to differences in amino acid profiles between animal and plant food. While a $2 \%$ higher energy expenditure may not appear to be clinically significant, it was believed that cumulatively these effects would contribute to weight loss over a longer period of time. This implies that, in order to enhance weight loss, increasing protein proportions in the diet alone may not be sufficient but

\section{KARGER}

Fax +4976145207 14

Information@Karger.de

www.karger.com (c) 2010 S. Karger GmbH, Freiburg 
Table 1. Anthropometry, energy and substrate metabolism, and satiety levels of participants measured during the 3 test meals in the whole-room calorimeter

\begin{tabular}{|c|c|c|c|c|}
\hline & Meat & Dairy & Soy & $\mathrm{p}$ \\
\hline \multicolumn{5}{|l|}{ Menu $^{\mathrm{a}}$} \\
\hline Breakfast & $\begin{array}{l}\text { toast with ham and } \\
\text { tomato, fruit juice }\end{array}$ & $\begin{array}{l}\text { toast with margarine } \\
\text { and jam, chocolate } \\
\text { milk shake }\end{array}$ & $\begin{array}{l}\text { toast with butter and } \\
\text { jam, chocolate soy milk } \\
\text { shake, soy powder }\end{array}$ & \\
\hline Lunch & $\begin{array}{l}\text { steak with potato and } \\
\text { vegetable, fruit juice }\end{array}$ & $\begin{array}{l}\text { salad with dressing and } \\
\text { grated cheese, yoghurt, } \\
\text { chocolate milk shake }\end{array}$ & $\begin{array}{l}\text { salad with dressing and } \\
\text { soy cheese, soy yoghurt, } \\
\text { chocolate soy milk } \\
\text { shake, soy powder }{ }^{\mathrm{b}}\end{array}$ & \\
\hline \multicolumn{5}{|l|}{ Anthropometry } \\
\hline Weight, kg & $71.1 \pm 17.2$ & $71.3 \pm 16.9$ & $70.7 \pm 17.0$ & 0.996 \\
\hline $\mathrm{BMI}, \mathrm{kg} / \mathrm{m}^{2}$ & $22.8 \pm 3.5$ & $22.9 \pm 3.4$ & $22.7 \pm 3.4$ & 0.990 \\
\hline Body fat, \% & $17.8 \pm 5.3$ & $18.3 \pm 6.7$ & $17.7 \pm 6.2$ & 0.966 \\
\hline \multicolumn{5}{|l|}{ Metabolism } \\
\hline Energy, kcal/8 h & $826.1 \pm 135.4$ & $814.0 \pm 152.4$ & $817.1 \pm 139.0$ & 0.987 \\
\hline Protein, g/8 h & $34.9 \pm 11.1$ & $36.2 \pm 12.6$ & $39.5 \pm 10.7$ & $0.038^{\mathrm{c}}$ \\
\hline Carbohydrate, g/8 h & $105.9 \pm 60.8$ & $99.4 \pm 34.1$ & $97.7 \pm 35.7$ & 0.951 \\
\hline Fat, g/8 h & $26.6 \pm 23.0$ & $28.2 \pm 17.6$ & $28.3 \pm 16.5$ & 0.997 \\
\hline \multicolumn{5}{|l|}{ Satiety levels, AUC } \\
\hline Question 1, inverted & $2,613.5 \pm 369.6$ & $2,683.8 \pm 694.0$ & $2,407.0 \pm 433.5$ & 0.283 \\
\hline Question 2 & $2,318.8 \pm 421.0$ & $2,392.3 \pm 636.4$ & $2,196.5 \pm 585.1$ & 0.431 \\
\hline Question 3 & $2,046.8 \pm 644.9$ & $2,319.8 \pm 577.0$ & $2,071.5 \pm 700.1$ & 0.288 \\
\hline Question 4, inverted & $2,306.3 \pm 484.7$ & $2,414.5 \pm 625.5$ & $2,153.5 \pm 515.1$ & 0.122 \\
\hline Combined score & $9,285 \pm 1,737$ & $9,727 \pm 2,236$ & $8,829 \pm 2,053$ & 0.296 \\
\hline
\end{tabular}

${ }^{a}$ Extra piece of fruit may be provided at each meal depending on the energy requirement.

'Instant Natural Protein Powder (Nature's Way, Australia).

'Significant difference between diets, $\mathrm{p}<0.05$. one must also pay attention to the source of protein. In practice, however, there are other considerations. Concerns have been expressed that an increased protein intake from meat sources may have other negative health impacts (such as type 2 diabetes [9], some cancers [10], coronary heart diseases [11]). Plant foods also appear to be placed in an inferior position in the weight management context, although these foods are nutrient-dense and good sources of fibre in the diet. In this study, we compared the thermogenic and fat-oxidising effects of 3 high-protein diets from predominantly meat, dairy, and plant sources during an 8 -h period in the human wholeroom calorimeter.

\section{Material and Methods}

Study Design and Protocol

This was an acute crossover feeding study of 3 high-protein meals consumed in a whole-room calorimeter. The order of diets was randomised, and the interval between stays was 3 days for males and 1 month for females to control for effects of menstrual cycle on energy metabolism. Participants fasted for $10 \mathrm{~h}$ overnight prior to their stays in the whole-room calorimeter. Participants' energy requirements were estimated using the Schofield equation. $65 \%$ of the energy expenditure was provided as breakfast and lunch (at 60 and $300 \mathrm{~min}$ ) during their 8-hour stays. Test meals were prepared by a dietician throughout the study to ensure consistency in food preparation. The study protocol was approved by the Human Research and Ethics Committee of the University of Wollongong.

\section{Participants}

Participants were recruited from both the University and the local community. Inclusion criteria were: aged $>18$ years, normal or overweight, non-smoker, not pregnant or lactating, and no food allergies. Volunteers who had an acute illness or conditions likely to alter metabolic rate such as thyroid abnormality were excluded from the study.

\section{Diet}

The 3 test meals contained protein predominantly from meat, dairy, and soy sources. The meat was lean beef and ham, the dairy comprised low-fat milk, cheese, and yoghurt. Soy was chosen as a plant alternative option because the commercial availability of soy protein powder enabled dietary modelling to match for macronutrient properties in the test meals. The amount of food provided to participants in the breakfast and lunch meals was based on individual calculated energy requirements [7]. Macroand micronutrient breakdowns of the meals were obtained using the FoodWorks nutrient analysis software (FoodWorks Professional 2007, Xyris Software, Brisbane, Australia). The carbohydrate, protein, and fat content in the test meals were kept consistent at 40,30 , and $30 \%$,respectively, of total energy provided (table 1).

\section{Anthropometry}

Height, weight (Tanita TBF622), percentage body fat (Bodystat 1500, Bodystat Ltd., Douglas, IM, UK), and waist-hip circumference were measured during a pre-study assessment. Bodystat 1500 is a tetrapolar bioelectrical impedance device which has been validated against the dualenergy X-ray absorptiometry method [12]. Weight and body fat measurements were repeated prior to each of the 3 calorimeter stays.

\section{Satiety Level}

Satiety levels of participants during calorimeter stays were assessed hourly through 4 questions in the visual analogue scales (VAS) [13]. 
Scores from the first 4 questions, where scores for question 1 and 4 were inverted, represent satiety levels.

\section{Energy Metabolism}

The whole-room calorimeter measures gaseous exchanges (oxygen consumption and carbon dioxide production) through air-tight, ventilated chambers under standard temperature, pressure, and dry (standard temperature, standard pressure; STPD) condition. Details on the operating protocol have been previously published [7]. Calculations of gaseous exchanges were based on measured in- and out-flow to the chambers according to Schoffelen et al. [14].

\section{Data Analysis}

Energy expenditure was calculated using the Weir equation [15]. Nitrogen excretion, which is used to calculate protein oxidation, was estimated from measured urinary urea. Carbohydrate and fat oxidation rates were calculated using the Frayn equation [16]. Hourly VAS scores were transformed into area under the curve (AUC) for all test diets. Differences in energy expenditure, rates of substrate oxidation, and VAS AUC were compared using a linear mixed model analysis (SPSS 15.0, SPSS Inc., Chicago, IL USA). Fat mass $(\mathrm{kg})$ and fat-free mass $(\mathrm{kg})$ were used as covariates for energy expenditure and substrate oxidation rates.

\section{Results and Discussion}

Twelve healthy participants ( 9 males, 3 females) were recruited, and all completed 3 stays in the calorimeter. Based on the World Health Organisation's (WHO) [17] classification, 1 male participant was obese while the others were normal-weight. The participants were aged $25.4 \pm 5.2$ years, with mean height $=175.3 \pm 11.7 \mathrm{~cm}$, waist $=76.5 \pm 10.9 \mathrm{~cm}(\mathrm{n}=11)$, hip $=98.9 \pm$ $8.4 \mathrm{~cm}(\mathrm{n}=11)$, and waist-hip ratio $=0.77 \pm 0.05(\mathrm{n}=11)$. The calculated energy requirements were 2,055 $\pm 363 \mathrm{kcal} / \mathrm{day}$ (using Schofield's equation), and meals provided to participants as breakfast and lunch (65\% of the daily requirements) in the whole-room calorimeter contained 1,336 $\pm 236 \mathrm{kcal}$. Mean habitual intakes of participants as measured by diet history interview were energy $=2,689 \pm 421 \mathrm{kcal} /$ day, protein $=117.6 \pm$ $27.1 \mathrm{~g} /$ day $(18.2 \pm 3.4 \%$ energy $)$, fat $=94.2 \pm 19.6 \mathrm{~g} /$ day $(31.6 \pm$ $3.7 \%$ energy $)$, carbohydrate $=307.6 \pm 54.2 \mathrm{~g} /$ day $(47.3 \pm 5.7 \%$ energy $)$, and alcohol $=12.0 \pm 18.8 \mathrm{~g} /$ day $(3.0 \pm 4.4 \%$ energy $)$.

Anthropometric measurements, dietary intake, and energy and substrate metabolic rates were measured (table 1). The energy expenditure, fat and carbohydrate oxidation rates were not significantly different between the 3 test meals. Protein oxidation was significantly different, with the difference found to lie between the meat and soy meals $(\mathrm{p}=0.012)$. The lower protein oxidation in the meat meal suggested a higher protein-sparing effect which could be linked to the high biological value of the meat protein [18]. This effect is important in weight loss, where there appears to be greater metabolic benefit in losing fat mass and also in retaining lean mass [1].

The energy expenditure following consumption of highprotein meals from predominantly meat sources was higher (not significant) than those from dairy and soy sources. This is consistent with the observation by Mikkelson et al. [8]. However, the magnitude of differences was lower than those re- ported by the group (meat was $1.5 \%$ higher than dairy and $1.1 \%$ higher than soy). These differences translate into approximately 36 and $27 \mathrm{kcal} /$ day higher in energy expenditure, respectively. Based on an energy density assumption of 7,700 $\mathrm{kcal} / \mathrm{kg}$ body weight [19], these results could mean an extra weight loss in the meat meal of $32.7 \mathrm{~g}$ compared to the dairy, and $24.5 \mathrm{~g}$ compared to soy. These figures may not be of clinical significance. Moreover, the fat oxidation rate induced by the meat meal was lower than the other 2 diets although they were not significant. The magnitude of the difference is also not clinically significant. Thus, even with a larger sample size the effect would likely to have little impact on weight loss.

The satiety level measured using the four-question VAS was not different between the 3 test diets (table 1). All diets showed equal capability to increase satiety levels which peaked at an hour post meals (both breakfast and lunch), and lasted for 180 min when the satiety levels dropped to almost similar levels to the baseline of study (overnight fast). Mean and combined scores for each question are presented in table 1.

The dairy and soy meals were similar as they contained similar food types (yoghurt, cheese, milk) but the cuisine varied with the meat meal. Despite the similarity, the foods from soy sources still had lower protein contents [20] such that additional soy protein had to be used to achieve the protein target of these meals.

\section{Conclusion}

In a high-protein diet context, meat protein-rich meals did not produce greater differences in thermogenic, fat-oxidising, and satiating effects than meals rich in dairy or soy protein. It is of note that it was difficult to achieve the same level of protein without supplementing with soy protein powder in the meals. This has significant implications for food product and vegetarian cuisine development. On the other hand, meals containing predominantly meat protein may produce protein-sparing effects which may be beneficial in terms of retaining lean body mass. This suggests that including a range of protein sources in a weight management diet is likely to be beneficial, and provides an argument for retaining some meat protein in the diet to support health body composition.

\section{Acknowledgements}

This research was funded by the National Centre of Excellence in Functional Food (NCEFF). We acknowledge the support of Dr. Arthur Jenkins, Mr. Harry Battam, and the Smart Foods Centre, School of Health Sciences, Faculty of Health, and Behavioural Sciences, University of Wollongong in various aspects of the implementation of this trial.

\section{Disclosure}

The authors declared no conflicts of interest. 


\section{References}

1 Halton TL, Hu FB: The effects of high protein diets on thermogenesis, satiety and weight loss: a critical review. J Am Coll Nutr 2004;23:373-385.

$\checkmark 2$ Volpi E, Lucidi P, Cruciani G, Monacchia F, Reboldi G, Brunetti P, Bolli GB, De Feo P: Contribution of amino acids and insulin to protein anabolism during meal. Diabetes 1996;45:1245-1252.

3 Labayen I, Diez N, Parra D, Gonzalez A, Martinez JA: Basal and postprandial substrate oxidation rates in obese women receiving two test meals with different protein content. Clin Nutr 2004;23: 571-578.

4 Stubbs RJ, van Wyk MCW, Johnstone AM, Harbron CG: Breakfasts high in protein, fat or carbohydrate: effect on within-day appetite and energy balance. Eur J Clin Nutr 1996;50:409-417.

5 Westerterp-Plantenga MS, Rolland V, Wilson SAJ, Westerterp KR: Satiety related to $24 \mathrm{~h}$ dietinduced thermogenesis during high protein/carbohydrate vs. high fat diets measured in a respiration chamber. Eur J Clin Nutr 1999;53:495-502.

6 Astrup A, Buemann B, Christensen NJ, Toubro $\mathrm{S}$ : Failure to increase lipid oxidation in response to increasing dietary fat content in formerly obese women. Am J Physiol 1994;266:E592-599.
7 Batterham MJ, Cavanagh R, Jenkins AB, Tapsell LC, Plasqui G, Clifton PM: High-protein meals may benefit fat oxidation and energy expenditure in individuals with higher body fat. Nutr Diet 2008; 65:246-252.

8 Mikkelsen PB, Toubro S, Astrup A: Effect of fatreduced diets on 24-h energy expenditure: comparisons between animal protein, vegetable protein, and carbohydrate. Am J Clin Nutr 2000;72:1135-1141.

$\checkmark 9$ Fung TT, Schulze M, Manson JE, Willett WC, Hu FB: Dietary patterns, meat intake, and the risk of type 2 diabetes in women. Arch Intern Med 2004; 164:2235-2240.

10 Tavani A, La Vecchua C, Gallus S, Lagiou P, Trichopolous D, Levi F, Negri E: Read meat intake and cancer risk: a study in Italy. Int J Cancer 2000; 86:425-428.

$11 \mathrm{Hu}$ FB, Rimm EB, Stampfer MJ, Ascherio A, Spiegelman D, Willet WC: Prospective study of major dietary patterns and risk of coronary heart disease in men. Am J Clin Nutr 2000;72:912-921.

12 Batterham MJ, Tapsell LC, Jenkins AB: A comparison of bioelectrical impedance and near infrared interactance with dual energy x-ray absorptiometry for the determination of body fat. Nutr Diet 2002;59:120-126.
13 Flint A, Raben A, Blundell JE, Astrup A: Reproducibility, power and validity of visual analogue scales in assessment of appetite sensations in single test meal studies. Int J Obes 2000;24:38-48.

14 Schoffelen PFM, Westerterp KR, Saris WHM, Hoor FT: A dual-respiration chamber system with automated calibration. J Appl Physiol 1997;83: 2064-2072.

15 Weir JB: New methods for calculating metabolic rate with special reference to protein metabolism. Nutrition 1990;6:213-221.

16 Frayn KN: Calculation of substrate oxidation rates in vivo from gaseous exchange. J Appl Physiol 1983; 55:628-634.

17 World Health Organization: Obesity: preventing and managing the global epidemic. WHO, Geneva, 2000.

18 Guthrie HA, Picciano MF: Human Nutrition. Mosby, St. Louis, MO, 1995.

19 Wishnofsky M: Caloric equivalents of gained or lost weight. Am J Clin Nutr 1958;6:542-546.

20 Tan S-Y, Tapsell LC, Batterham MJ, Charlton K: Defining the functional properties of dietary protein and protein-rich foods in human energy expenditure. Nutr Diet 2008;65:S66-S70. 